http://kitaibelia.unideb.hu/

ISSN 2064-4507 (Online) • ISSN 1219-9672 (Print)

(C) 2016, Department of Botany, University of Debrecen, Hungary

22 (1): 64-70.; 2017

DOI: $10.17542 /$ kit.22.64

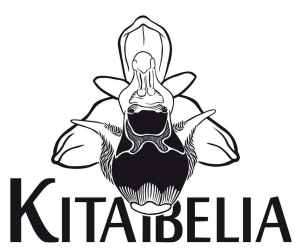

\title{
Egyéves füzények (Lythrum) Magyarországon: a Hyssopifolia alnemzetség hazai adatainak revíziója
}

\author{
MESTERHÁZY Attila \\ H-4024 Hortobágyi Nemzeti Park Igazgatóság, Debrecen, Sumen utca 2.; amesterhazy@gmail.com
}

\section{Annual Lythrum species in Hungary: revision of the subgenus Hyssopifolia}

\begin{abstract}
Four ephemeral Lythrum species have been recorded from Hungary so far. Lythrum hyssopifolia is widely distributed in the whole country. Most occurrences of L. tribracteatum are located in southeastern Hungary and alongside the Danube. The Central Asian L. linifolium was reported from a single locality (Tiszaug village, E Hungary) in 1954, which is the only European record of this species. However, we have ascertained that the voucher specimen of this record differs from L. linifolium in some morphological traits, but strongly resembles L. borysthenicum that is distributed in the Mediterranean and steppe regions of eastern Europe. Based on our revision we suggest deleting $L$. linifolium from both Hungarian and European checklists. The former Hungarian occurrence of $L$. thesioides is confirmed by vouchers.
\end{abstract}

Keywords: ephemeral wetland vegetation, Hungarian flora, Lythrum borysthenicum, L. linifolium, L. thesioides

Összefoglalás - Magyarország területéről eddig az apró termetű, egyéves füzények 4 fajának előfordulását közölték. A Lythrum hyssopifolia az ország nagy részén elterjedt. A L. tribracteatum jóval ritkább, előfordulásai főként a Tiszántúl déli részére és a Duna mentére korlátozódnak. A belső-ázsiai elterjedésű lenlevelű füzény (L. linifolium) egyetlen európai adata hazánkból származik. Az 1954-ben Tiszaug mellett gyűjtött példány azonban több jellegében is eltér a lenlevelü füzénytől, viszont nagyfokú egyezést mutat a Mediterráneumban és a kelet-európai sztyeprégióban élő L. borysthenicum-mal. Ez alapján javasoljuk a L. linfolium törlését a hazai és az európai flórából egyaránt. A negyedik hazai taxon (L. thesioides) egykori magyarországi előfordulását (Nagytétény) herbáriumi példányok bizonyítják, de a faj jelenlegi előfordulása bizonytalan.

Kulcsszavak: iszapnövény, Lythrum borysthenicum, L. linifolium, L. thesioides, magyar flóra

\section{Bevezetés}

A füzény (Lythrum L.) nemzetségben Magyarországon két évelő fajtól (L. salicaria $L$., $L$. virgatum L.) eltekintve egyéves taxonokat tartunk számon (MoLNÁR V. 2009), amelyeket a Hyssopifolia Koehne alnemzetségbe sorolnak. A kistermetű, egyéves füzényfajok közül hazánkban régóta ismert a L. hyssopifolia L. és a L. tribracteatum Salzm. in Spreng.

Az Európában rendkívül ritka Lythrum thesioides M. Bieb. herbáriumi revízió során került elő Magyarországon: Degen Árpád Budapest környéki L. hyssopifolia gyűjtései között bukkant rá Zsák Zoltán (ZsÁK 1954). Ezt követően Tiszaug településtől északra lévő „Nagybokros” szikes laposaiban Bodrogközy György és Timár Lajos L. hyssopifolia-k között néhány érdekes apró füzényre lettek figyelmesek. A növényeket határozásra elküldte Zsák 
Zoltánnak, aki azokat a Belső-Ázsiában élő L. linifolium Kar. et Kir. fajjal azonosította. A felfedezés jelentőségét növelte, hogy a lenlevelű füzény nemcsak Magyarországra, hanem egész Európára újként került elő (TIMÁr \& BODROGKöZY 1955). A Flora Europaea (WEBB 1964) nem adott hitelt a faj magyarországi előfordulásnak, mivel - a Magyarországon gyüjtött példány vizsgálata nélkül - valószínűsítették a $L$. thesoides-szel való tévesztést. A lenlevelü füzény a Flora Europaea-ban közölt kétely ellenére és annak dacára, hogy 1954 óta, a kifejezett keresés ellenére sem került elő, 1993-ban felkerült a védett fajok listájára. Jelenlegi természetvédelmi értéke: $5000 \mathrm{Ft}$. Mivel a növényt már több mint ötven éve nem találták meg újra, a hazai vörös lista (KIRÁLY 2007) kipusztultként tartja nyilván. A faj egykori hazai előfordulásának tisztázása miatt tartottam szükségesnek az alnemzetség hazai gyüjtéseinek áttekintését és a hazánkból közölt fajok külföldi herbáriumi anyagokkal történő összevetését.

Az alakgazdag, szórványos előfordulású, egyéves füzények számos esetben okoznak határozási nehézségeket. Ez leginkább a Kelet-Európában és az Ázsiában leírt fajoknál érhető tetten. Problémás a $L$. theodori Sosn. és a $L$. schelkovnikovii Sosn. elkülönítése a $L$. hyssopifolia-tól, de a Közép-Ázsia félsivatagos területein élő $L$. nanum Kar. et Kir. és $L$. komarovii Murav elválasztása sem egyértelmű (MURAVJEV 1949). Hazai adata a tőlünk keletre élő egyéves füzények közül a $L$. thesioides-nek és a L. linifolium-nak van, ezért a növénytári példányok ellenőrzése kapcsán e két fajról gyűjtöttem információkat.

\section{Anyag és módszer}

Az egyéves füzények hazai gyújtéseit a Magyar Természettudományi Múzeum Növénytárában (BP) vizsgáltam meg. A külföldi Lythrum anyag tanulmányozása a Kew (K), Párizs (P), Szentpétervár (LE), Moszkva (MW), Almati (AA), Bologna (BOLO), Firenze (FI) és Verona (VER) herbáriumokban történt. A határozáshoz MuRAVJEv (1949), WeBB (1964) és NiETO FELINER (1997) munkáit használtam fel. A növények vizsgálatát sztereomikroszkóppal végeztem.

\section{Eredmények}

A Lythrum hyssopifolia L. Európa északi területeit kivéve kontinensünkön általánosan elterjedt (WEBB 1964). Kelet felé megritkul, Nyugat-Szibériában már csak szórványos előfordulású (MURAVJEV 1949). Hazánk minden régiójában gyakori faj, vízpartok, pocsolyák iszaptársulásaiban gyakran megjelenik, de előfordul belvizes szántókon is (MOLNÁR \& PFEIFFER 1999).

A Lythrum tribracteatum Salzm. in Spreng. fóleg a Mediterrán régióban és KeletEurópában található meg, áreája Magyarország keleti felétől Közép-Ázsiáig húzódik (MuRAVJeV 1949, WeBB 1964). Magyarországon adatai a Nagy-Alföldre korlátozódnak, ahol a Duna-völgyében és a Dél-Tiszántúlon fordul elő (MoLNÁr \& PFEIFFER 1999).

A Dunától nyugatra nagyon ritkán jelenik meg, az utóbbi években csak a Kelet-Bakonyból (BAUER \& KIRÁLY 2011) és a Dráva mentéről (CSIKY \& OLÁH 2006) van aktuális adata.

A Lythrum thesioides M. Bieb.-t (syn.: L. geminiflorum Bert.) Steven 1800-as gyüjtései alapján Marschall von Bieberstein írta le (BIEBERSTEIN 1808). A példányok a Kaukázus északi előterében lévő Sztavropoli-hátságról származnak, pontos helymegjelölés nélkül („Ex Caucaso demifsion in distriction Stavropoli"). A Sztavropol melletti Kravtsovo tó partián még az 1950-es években megtalálták, de a faj a régióból azóta nem került elő (N. Likhovid in litt.). Oroszország európai részéről van még egy adat a Volgográdtól délre lévő sareptai tavak mellől. Itt Becker 1853-ban gyűjtötte. Kazahszánból egyetlen gyűjtés ismert, még 1927-ből Ayryuk helymegjelöléssel. A Flora Iranica (PoLATSCHEK \& RECHINGER 1968) egy adatot közöl Iránból (Stapf, K, 1415) és kettőt Afganisztánból (Griff, K, 1232 és 2308). Az afganisztáni 
gyűjtéseket egyébként eredetileg L. linifolium-ként azonosították, egyes forrásokban (MURAVJEV 1949, PoDlECH 2012) is ezen a néven szerepelnek.

A faj a leírása után nem sokkal Dél-Európában is előkerült. Olaszországban gyűjtötte Paolo Barbieri a Pó síkságról Mantova tartományból „Rotta” település (ma: Villarotta) mellől 1837. szeptember 24-én L. thymifolium néven, melyet BERTOLONI (1842) L. geminiflorum Bert.-ként ír le. A típuspéldány a bolognai egyetem herbáriumában található. A szerző a gyűjtési helyet Reggio Emilia régióhoz sorolja. A gyűjtés közeléből még Tagliata helységnevet említi, ami viszont már Lombardia tartomány része. Bár PIGNATTI (1982) mindkét régióból jelzi a fajt, valószínű, hogy jelen esetben csak egyetlen lelőhelyről van szó. Később FIORI (1925-1929) jelzi Veronától délre „Demorta” helységnévvel (ma: Corte Demorta). Érdekes, hogy a veronai múzeumban csak a Barbieri által a Pó síkságról gyűjtött példány található meg „Mantova” helymegjelöléssel, így ennek az előfordulásnak bizonyító példányai nem ismertek. A növényt Olaszországból később nem sikerült újra kimutatni (CoNTI et al. 2005).

Franciaországban az ország déli részén lévő Beaucaire település mellett a Jonquéres tó partján (Grad tartomány) gyűjtötték 1849-ben. Később előkerült Drôme és Vaucluse régiókból is (OLIVIER et al. 1995). A lelőhelyek egy viszonylag kis területen, Avignon és Nîmes között találhatók. A fajt itt sokáig kipusztultnak hitték, de Grad tartományban Languedoc melletti Capelle tó partján és Beaucaire város közelében újra felfedezték 2001-ben. Előbbi lelőhelyén 2004 óta nem került elő, míg utóbbin kevés példányszámban, de rendszeresen találják (P. Grillas és A. Gazaix in litt.).

A L. thesioides-t hazánkban ZsÁK (1954) mutatta ki először, Degen Árpád füzénygyưjtéseinek revíziója során. A fajt közös terepbejárásuk során L. hyssopifolia-ként a Nagytétény városrészhez tartozó Baross-telep közelében gyűjtötték 1917.07.29-én. A nagytétényi példányok a MTM Növénytárának Carpato-Pannonicum gyüjteményében ma is megtalálhatók. A cikkben jelzett „Puszta-Halomegyháza inter Üllő et Pusztagyál 1917.07.31” cédulával ellátott példányok azonban nincsenek meg a L. thesioides anyagban. A L. hyssopifolia gyưjteményben azonban ismert egy gyüjtés Degen-től „In agrillosis humidis inter Üllő et Puszta-Gyál 1917.07.31”. A herbáriumi lapon fiatal, de egyértelműen határozható $L$. hyssopifolia példányok vannak. Bizonyító példányok hiányában tehát az üllői előfordulást kétesnek kell tekintenünk.

A Lythrum linifolium Kar. et Kir. (syn.: L. thseioides subsp. linifolium (Kar. et Kir.) Koehne) fajt 1841-ben írták le Dzsungáriából (ma részben Kazahsztán területe) származó példány alapján (KARELIN \& KIRILOV 1841). Üzbegisztánban Taskent és Szamarkand körzetekből jelzik (VVEDENSKY 1969). MURAVJEV (1949) Észak-Mongóliából is hozza, melynek forrása valószínűleg a szentpétervári Komarov Intézetben (L) lévő G.N. Potanin 1876-ban gyűjtött nehezen lokalizálható („Mongolia borealis”) herbáriumi lapja. A legújabb mongóliai flóramű (GRUBOV 2001) a fajt a bizonyító példány ellenére sem jelzi az országból. A tanulmányozott herbáriumi példányok alapján a legtöbb gyűjtése Kazahsztánból, az ország keleti és északkeletei részéből van, döntően a múlt század közepéből. Utolsó ismert adata 1992-re tehető, mikor is a kínai határ mentén a Fekete Irtis folyó zátonyán találtak egyetlen példányt (TARAN 1993). A MTM Növénytár Carpato-Pannonicum gyüjteményében két herbáriumi lap található Lythrum linifolium néven azonosítva. Az egyiket Felföldy Lajos gyűjtötte 1996-ban Apajon, de ez az adat nem került be a köztudatba. A herbáriumi lapon több apró termetű füzény található, melyek szálas levelűek ugyan, de a megnyúlt, hengeres termés alapján azok egyértelmúen az alacsony füzényhez (L. hyssopifolia) tartoznak.

A Bodrogközy György által 1954-ben Tiszaug mellett gyűjtött példány (2. ábra) viszont nem azonosítható a hazánkban jól ismert kistermetű, egyéves fajokkal.

A szentpétervári és moszkvai herbáriumokban lévő L. linifolium példányok tanulmányozása során viszont a Tiszaugon és a Közép-Ázsiában gyüjtött növények között több eltérés tapasztalható (1. táblázat). 
MESTERHÁZY (2017) - Kitaibelia 22 (1): 64-70.

1. táblázat. A Lythrum linifolium, a L. borysthenicum és a „L. linifolium” Tiszaug mellett 1954-ben gyüjtött bizonyító példányának összehasonlítása

Table 1. Comparison of Lythrum linifolium, L. borysthenicum and the voucher specimen of "L. linifolium" collected by Gy. Bodrogközy near Tiszaug (E Hungary) in 1954

\begin{tabular}{|c|c|c|c|}
\hline & Lythrum linifolium & $\begin{array}{c}\text { Tiszaugi példány / } \\
\text { specimen collected } \\
\text { near Tiszaug }\end{array}$ & L. borysthenicum \\
\hline $\begin{array}{l}\text { Szőrözöttség / } \\
\text { Hairinesss }\end{array}$ & $\begin{array}{l}\text { minden részében kopasz / } \\
\text { glabrous in all parts }\end{array}$ & $\begin{array}{l}\text { termése elszórtan apró } \\
\text { serteszőröktől érdes / } \\
\text { more or less scabrid- } \\
\text { hispid }\end{array}$ & $\begin{array}{l}\text { apró serteszőröktől } \\
\text { érdesek, ritkán } \\
\text { kopaszak / more or less } \\
\text { scabrid-hispid, rarely } \\
\text { glabrous }\end{array}$ \\
\hline $\begin{array}{l}\text { Levélalak / } \\
\text { Form of leaf }\end{array}$ & lándzsás / lanceolate & $\begin{array}{l}\text { visszás tojásdad / } \\
\text { obovate }\end{array}$ & $\begin{array}{l}\text { visszás tojásdad, lapát / } \\
\text { oblong-oblanceolate to } \\
\text { broadly obovate, } \\
\text { sometimes sphatulate }\end{array}$ \\
\hline $\begin{array}{l}\text { Terméses csésze / } \\
\text { Capsule }\end{array}$ & $\begin{array}{l}\text { harang alakú, } 2-2,5 \times \\
\text { hosszabb a szélességénél } \\
\text { (1. ábra), gyengén } \\
\text { erezett / campanulate, } \\
2-2,5 \text { times longer than } \\
\text { wide (Fig. 2), weakly } \\
\text { veined }\end{array}$ & $\begin{array}{l}\text { bögre formájú, } \\
\text { erőtelesen erezett ( } 2 \text {. } \\
\text { ábra), mely 1,2-1,5 × } \\
\text { hosszabb a } \\
\text { szélességénél/ } \\
\text { cylindrical with distinct } \\
\text { weins, } 1,2-1,5 \times \text { longer } \\
\text { than wide }\end{array}$ & $\begin{array}{l}\text { bögre vagy harang } \\
\text { alakú, csak kissé } \\
\text { hoszabb a } \\
\text { szélességénél/ globular } \\
\text { to shortly cylindrical, } \\
\text { slightly longer than } \\
\text { wide }\end{array}$ \\
\hline $\begin{array}{l}\text { Csészecimpa } \\
\text { függelékének } \\
\text { hossza / Length } \\
\text { of epicalyx- } \\
\text { segment } \\
\end{array}$ & $\begin{array}{l}\text { jóval kisebb a } \\
\text { csészecimpáknál (kb. } \\
1 / 5-e) / 1 / 5 \text { of deltate } \\
\text { sepals }\end{array}$ & $\begin{array}{l}\text { a csészecimpa kb. fele / } \\
\text { half of deltate sepals }\end{array}$ & $\begin{array}{l}\text { a csészecimpa fele, de } \\
\text { néha eléri azt / half of } \\
\text { deltate sepals,but } \\
\text { sometimes equalling } \\
\text { that }\end{array}$ \\
\hline
\end{tabular}

A vizsgált bélyegek és a külföldi herbáriumokban lévő példányokkal való összehasonlítás alapján a tiszaugi növény egyértelműen nem azonosítható a L. linifolium-mal. A bögre alakú serteszőrös termés és a levelek alakja alapján viszont jelentős hasonlóságot mutat az Európában jóval elterjedtebb $L$. borysthenicum (Schrank) Litv.-mal. Ennél a fajnál a szirom hamar lehullik, ami szintén jellemző a tiszaugon gyűjtött növényre. Az eurázsiai füzények közül a termés szőrözöttsége és a korán lehulló szirom más fajnál nem figyelhető meg, ezért egyes Kelet-európai munkák (MURAVJEV 1949, JORDANOv 1979) a fajt külön nemzetségbe (Middendorfia Trautv.) sorolják.

A MTM Növénytárában Lythrum linifolium néven azonosított példányok adatai:

Comit Pest, in via agricellaceo-lutosa iuxta canalem „XXXI csatorna” prope pagum Apaj. 1996.08.09. leg./det. Dr. Felföldy Lajos (590209).

Rev.: Lythrum hyssopifolia L. 2008.02.13. Mesterházy Attila

Szolnok. Tiszaug-Bokros. Solum natronatum. Ass. Heleocharis palustris 1954.06.30. leg. Bodrogközy György.

Rev.: Lythrum borysthenicum (Schrank) Litv. 2016.11.08. Mesterházy Attila 


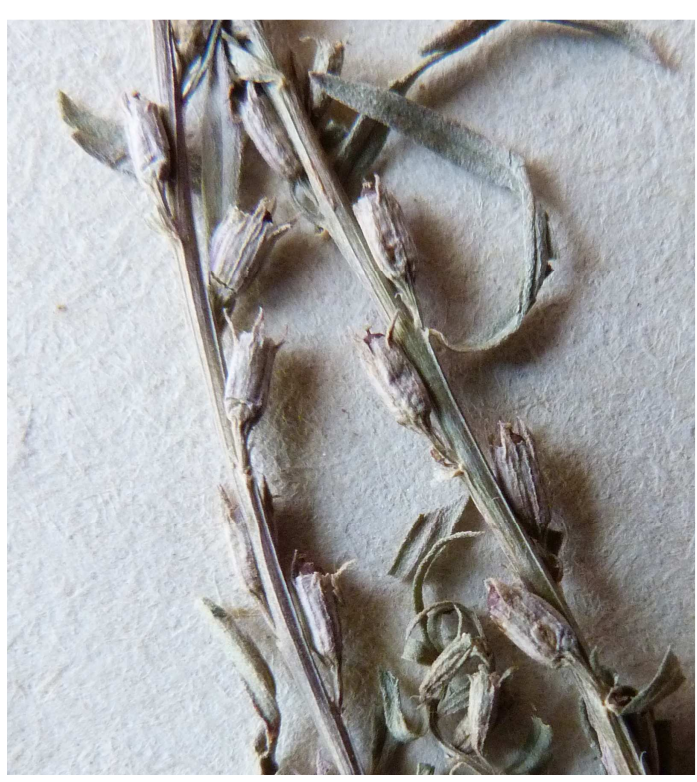

1. ábra: Lythrum linifolium egy herbáriumi példányának részlete Kazahsztánból (Szentpétervári Komarov Intézet, LE; Fotó: Mesterházy A.)

Fig. 1. Part of a Lythrum linifolium specimen collected in Kasakhstan (Komarov Botanical Institute, St. Petersburg, LE;

Photographed by A. Mesterházy)

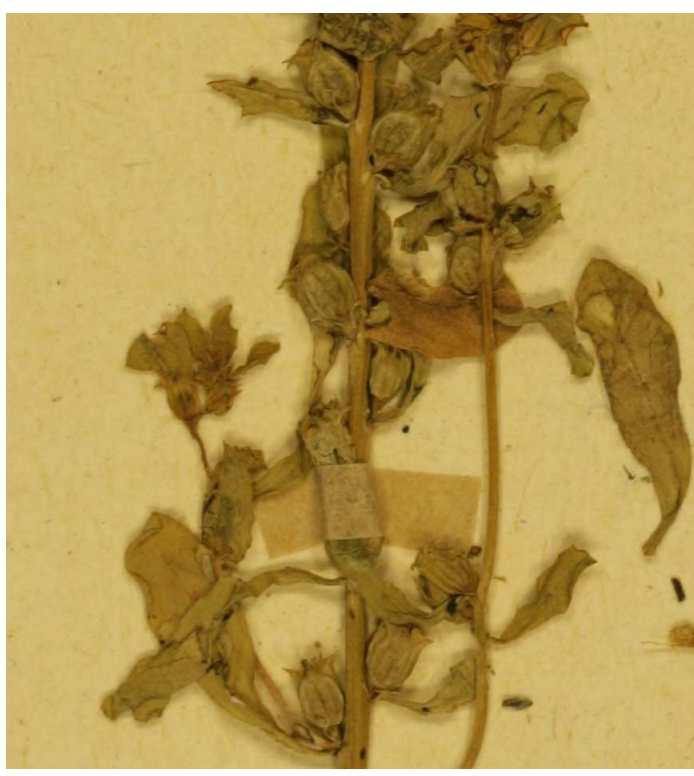

2. ábra: A Tiszaug mellett 1954-ben gyűjtött (eredetileg Lythrum linifolium néven azonosított) L. borysthenicum példány (BP 196737) részlete (Fotó: Barina Z.)

Fig. 2. Part of the Lythrum borysthenicum specimen (BP 196737) collected near Tiszaug in 1954 (originally identified as L. linifolium) (Photographed by Z. Barina)

A Lythrum borysthenicum (Schrank) Litv. (syn.: Peplis borysthenica Schrank, Middendorfia borysthenica (Schrank) Trautv.) egyéves kúszó vagy felemelkedő szárú növény. A szár (2,5)3-15(-25) cm hosszú, általában érdes, de gyakran lekopaszodik. Levele 5-20 × 2-8(-13) $\mathrm{mm}$, visszás tojásdad vagy lapát alakú, ülő. A levelek váltakozó vagy átellenes állásúak. A virágok a levelek tövében, magánosan vagy ritkán párban állnak négy- vagy öttagúak, ülők. A murváskodó levél sallangos, 1,5 mm hosszú. A terméses csésze bögre vagy harang alakú 2-4 mm hosszú, 0,8-1,7-szer hosszabb a szélességénél, gyakran pirosas színű. A csészék feltűnően erezettek, apró serteszőröktől érdesek. A csészecimpák függelékei ár alakúak, a csészecimpáknak elérik a felét vagy azokkal egyenlők, de esetenként kissé túl is nyúlhatnak rajtuk. A termés gömbölyű vagy kissé hengeres, rövidebb a csészénél. Az érett mag sötétbarna $0,3 \times 0,5 \mathrm{~mm}$, széles tojásdad.

A faj diszjunkt elterjedést mutat: előfordul a Mediterráneumban és Kelet-Európa erdőssztyep- és sztyepzónájában (GREUTER et al. 1989). Az Ibériai-félszigeten Spanyolországban (Galícia, Valencia, Gerona, Asztúria) és Portugália északi részén szórványosan található meg (NIETO FELINER 1997).

Olaszországban előfordulásainak zöme Szicília, Szardínia területére esik, de Toscana és Lazio tartományokban is megvan (PIGNATTI 1982). Franciaországban Loire, Garonne tartományokban és a Rhone völgyében nagyon ritka, míg Korzikán gyakori (GRILLAS et al. 2004). Görögországi előfordulásai Krétáról, Peleponnészosz-félszigetről és az Égei-tengeri szigetekről ismertek (STRID 2016). Bulgáriában csak a Marica-folyó völgyében Plovdiv környékén találták (JORDANOV 1979). Törökországban 6 helyről közlik (DAVIS 1988), de ritka Palesztinában is (ZOHARY 1987). Afrika északi részén megtalálható az Atlasz-hegység előterében (Marokkó, Algéria, Tunézia), de ottani gyakoriságáról nincs aktuális információ. Ukrajnában, 
az ország keleti régiójából, a Krímből és Kijev környékéről van adata (KLOKOV 1955). A fajt egyébként a Dnyeper alsó szakaszáról származó példány alapján írták le, fajnevét a folyó latin elnevezéséről (Borysthenes) kapta. Elterjedése kelet felé Nyugat-Szibériáig nyúlik (MURAVJEV 1949). A rendelkezésünkre álló irodalmi források alapján, a faj egész elterjedési területén ritka vagy szórványos előfordulású, egyedül a Földközi-tenger medencéjének nyugati részén van több adata.

A Mediterrán régióban jellegzetes élőhelyei a sziklás, köves területek időszakos tócsái (temporary pools), de előfordul tavak litorális zónájában, belvizekben, elárasztott ártereken (GRILLAS et al. 2004, MURAVJEV 1949). Hazánkban mentett oldali szikes rét belvizes mélyedéséből került elő (TIMÁR \& BODROGKÖZY 1955). 2012-ben a fajt Oroszország Volgográd régiójában kontinentális mocsár (helyi néven: liman) iszapos szegélyében találtuk (LAKTIoNOV et al. 2013).

A növény magyar nevének, a latin fajnév alapján a „Dnyeper-menti füzény” elnevezést ajánljuk, egyúttal javasoljuk a lenlevelű füzény (Lythrum linifolium) törlését a hazai flórából. Megjegyezzük, hogy az Új magyar füvészkönyvben (KIRÁLY et al. 2011: 305.) megjelent $L$. linifolium rajz a tiszaugi növény alapján készült (Molnár V. A. ex verb.), így az 1199. ábra szintén a L. borysthenicum bélyegeit mutatja be.

A hozzáférhető herbáriumokban található kevés gyüjtés alapján arra következtethetünk, hogy a Lythrum linifolium és L. thesioides egyaránt széles elterjedésű, de nagyon ritka előfordulású. Elkülönítésük leginkább méretek alapján történik. A L. linifolium a L. thesioides-tôl nagyobb szirma, csészéje és a terméses csésze mérete alapján különbözik (MURAVJEV 1949). Az egyéves füzényekről általánosságban elmondható, hogy a vegetatív és generatív részeinek méretei gyakran változnak, ezért a szóban forgó bélyegek alapján a két faj elkülönítése gyakran problémás. A határozási nehézségekre már KoEHNE (1881) felhívta a figyelmet és a nagyfokú hasonlóság miatt a L. linifolium-ot a L. thesioides alfajának tekintette. Az alfaji szintú elkülönítés azonban az ilyen széles elterjedésű, de rendkívül kevés példányszámban ismert egyéves iszaplakó fajoknál nehezen értelmezhető. Lehetséges, hogy csíráztatási és nevelési kísérletek és az összes fellelhető egyed morfológiai paramétereinek összehasonlítása alapján a két taxon nem különül el egymástól és végül a $L$. linifolium és a $L$. thesioides egyazon faj két elnevezésének bizonyulnak.

\section{Köszönetnyilvánítás}

A herbáriumi adatgyűjtésben Barina Zoltán (MTM Növénytár, Budapest), Jane Browning (Royal Botanical Garden Kew, Richmond, Nagy-Britannia), Andrew Efremov (Omsk State University, Omszk, Oroszország), Annalisa Managalia (Università di Bologna, Bologna, Olaszország), Chiara Nepi (Università di Firenze, Firenze, Olaszország), Nótári Krisztina (Debreceni Egyetem) és Francesco di Carlo (Natural History Museum, Verona, Olaszország) segítették munkámat. Patrick Grillas, Antoine Grazaix (Tour du Valat, Franciaország), Nicola M.G. Ardenghi (University of Pavia, Pavia, Olaszország), Georgy Taran (West Siberian Branch of V.N.Sukachev Institute of Forest of SB RAS, Novoszibirszk, Oroszország) és Natalia Likhovid (North Caucasian Federal University, Sztavropol, Oroszország) a fajokkal kapcsolatos információkat osztották meg velem. Segítségüket ezúton is köszönöm.

\section{Irodalom}

BAUER N. \& KIRÁLY G. (2011): Néhány alföldi Nanocyperion és mocsári növényfaj megjelenése Öskü mellett. - Kitaibelia 15[2010]: 180-182.

BERTOLONI A. (1842): Flora Italica: sistens Plantas in Italia et in insulis cirstumtantibus sponte nascentes. Vol. 5., Bononiae, $654 \mathrm{pp}$.

Bieberstein M. (1808): Flora Taurico-Caucasica. Charkouiae: Typis Academicis, 367 pp.

Conti F., AbBate G., AlEsSAndrini A. \& Blasi C. (eds) (2005): An annotated checklist of the Italian vascular flora. - Palombi e Partner, Roma, 420 pp. 
CSIKY J. \& OLÁH E. (2006): A Drávamenti-síkság Nanocyperion jellegű fajainak vörös listája. - Natura Somogyensis 9: 5-26.

Davis P.H., Mill. R.R. \& Tan K. (eds) (1988): Flora of Turkey and the East Aegean Islands. Vol. 10. University Press, Edinburgh, 590 pp.

FIORI A. (1925-29): Nouva flora analitica d' Italia. Vol 2. - Tipografia di M. Ricci. via San Gallo, Firenze, $1136 \mathrm{pp}$.

Greuter W., BuRdet H.M. \& Long G. (eds) (1989): Med-Checklist. - Conservatoire et Jardin botanique de la Ville Genève / Botanischer Garten \& Botanisches Museum Berlin-Dahlem.

Grillas P., Gauthier P., Yavercovski N. \& Perennou C. (2004): Les mares temporaires mediterraneennes: Fiches especes. Vol. 2. - Tour du Valat, Arles, 130 pp.

GRUBov V.I. (2001): Key to the vascular plants of Mongolia. - Science Publisher, Moscov - St. Petersburg, $817 \mathrm{pp}$.

JoRDANOv D. (1979): Flora Reipublicae Popularis Bulgaricae. Vol 7. - In Aedibus Acedemiae Scientiarum Bulgaricae, Sofia, $437 \mathrm{pp}$.

KARELIN G. \& Kirilov J. (1841): Enumeratio plantarum anno 1840 in regionibus Altaicis, et confinibus collectarum. - Bull. Soc. Nat. Moscou 14: 369-542.

KIRÁLY G. (szerk.) (2007): Vörös Lista. A magyarországi edényes flóra veszélyeztetett fajai. - Saját kiadás, Sopron, 73 pp.

KirÁLY G., MolNÁR V. A. \& VIRóK V. (szerk.) (2011): Új magyar füvészkönyv. Magyarország hajtásos növényei. Ábrák. - Aggteleki Nemzeti Park Igazgatóság, Jósvafő, 676 pp.

KLoKov M.V. \& VISZJULina O.D. (eds) (1955): Flora URSR. Vol. 7. - Bidavnictbo Akademii Nauk Ukrainckoui RSR, pp. 401-410.

KoEHNE E. (1881): Lythraceae monographice describuntur. - Botanische Jahrbücher Systematik 1: 142-157.

Laktionov A.P., Bobrov A.A., Mesterházy A., Meshcheryakova N.O., PifKo D. \& Nurmuhambetova D.E. (2013): $\mathrm{New}$, critical and rare taxa the flora of northern and eastern Caspian region. - Yestestvennye Nauki 3 (44): 16-21.

MolnÁr V.A. (2009): Lythraceae. - In: KiRÁLY G. (szerk.), Új magyar füvészkönyv. Magyarország hajtásos növényei. Határozókulcsok. Aggteleki Nemzeti Park Igazgatóság, Jósvafö, pp. 295-296.

MolnÁr V.A. \& PFEIfFER N. (1999): Adatok hazai Nanocyperion-fajok ismeretéhez II. Iszapnövényzetkutatás az ár- és belvizek évében Magyarországon. - Kitaibelia 4: 391-421.

Muravjev O.A. (1949): Lythraceae. - In: Komarov V.L. (ed.), Flora of USSR. Volume XV. (Malvales, Parietales, Myrliflorae). Izdatel'stvo Akademii Nauk SSSR, Moscov-Leningrad, pp. 536-548.

Nieto Feliner F. (1997): Lythrum. - In: Castroviejdo S., Aedo C., Benedí C., Laínz M., Munoz Garmendia F., Nieto Feliner G. \& Paiva J. (eds), Flora Iberica. Vol. 8. Real Jardín Botánico, CSIS, Madrid, 15-25 pp.

Olivier L., Galland J.-P. \& MauRin H. (1995): Livre rouge de la flora menacée France. Tome I: Espéces prioritaires. - Collection patrimoines naturels, Instutu d"Ecologie et de gestion de la biodiversité, service du patrimoine naturel, Paris, $486 \mathrm{pp}$.

PignatTi S. (1982): Flora d' Italia. Vol. 2. - Bologna, 731 pp.

PoDlech D. (2012): Checklist of the flowering plants of Afghanistan. - München, $301 \mathrm{pp.}$

PolatscheK A. \& Rechinger K.H. (1968): Lythraceae. - In: Flora Iranica. Vol 51. Akademische Druck u Verlagsanstalt, Graz, p. 10.

STRID A. (2016): Atlas of the Aegean Flora. - Englera 33: 1-878.

TARAN G.S. (1993): On syntaxonomy of Black Irtysh flood-plain ephemerous vegetation. - Siberian Journal of Biology 5: 79-84.

Timár L. \& Bodrogközy Gy. (1955): A Lythrum linifolium Karel. et Kiril. Magyarországon. - Botanikai Közlemények 47: 134-138.

Vvedensky A.I. (ed.) (1969): Flora Uzbekistanica. Vol. 4. - Academiae Scientiarium UzSSR, Taskent, 237 pp.

Webi D.A. (1964): Lythrum L. - In: Tutin T.G., Heywood V.H., Burges N.A., Moore D.M., Valentine D.H., Walters S.M., WebB D.A. (eds), Flora Europaea. Vol. 2. University Press, Cambridge, 300-303 pp.

Zohary M. (1987): Flora Palaestina. Vol. 2. (Platanaceae-Umbelliferae). - The Israel Academy of Science and Humanities, Jerusalem, $489 \mathrm{pp}$.

Zsák Z. (1954): A Lythrum thesioides M.B. hazánkban. - Botanikai Közlemények 45: 272-274.

Beérkezett: 2016. 12. 05. • Elfogadva: 2017. 02. 14. 